\title{
Student Performance Shows Slight Improvement When Open Notes are used during Information Systems Exams
}

\author{
Doris G. Duncan \\ California State University, East Bay (Hayward), \\ Hayward, California USA \\ doris.duncan@csueastbay.edu \\ Executive Summary
}

Students often ask about the use of reference aids during exams in most disciplines. These aids are most commonly notes they have taken, textbooks, handouts, or perhaps access to information stored on computers and/or the Internet. Although the practice of using reference aids may be common, the author was unable to locate much relevant research previously conducted on this topic. A research project as this one was long overdue.

This article summarizes findings of teaching eight sections of the same information systems college course in the same format with one major exception. Five sections had notes available for reference during the final exam whereas three sections did not. The author's primary hypothesis that students in the five sections using notes would perform significantly better than the other sections on the exam was not supported. The author also analyzed exam results for the sections allowed to use notes and found there was a significant difference in how individual students who chose to use notes performed compared to those who chose not to use notes. Thus, the supplemental hypothesis number two was supported. This study suggests that individual students will perform slightly better on exams if they prepare reference notes to use. Both faculty and students who want to see good test results have reason to promote the use of reference notes during exams.

One or many of the following 10 factors may have influenced outcome of this study: 1) Since use of notes is optional, many students may choose not to use them and thus negate the potential impact on a course section, 2) Allowing notes may instill a false sense of confidence such that students may procrastinate and not prepare thoroughly for the exam, 3) Limiting reference notes to one page may be too similar to allowing no reference notes, 4) The opportunity to use notes may provide an incentive for some students to prepare thoroughly for the exam, 5) The quality of student-prepared notes can vary considerably. 6) The final exam, although difficult, may be inherently easier than the midterm, 7) Results do not show why students who prepared notes did slightly better. It could be because they spend more time and mental synthesis in preparation for

Material published as part of this publication, either on-line or in print, is copyrighted by the Informing Science Institute. Permission to make digital or paper copy of part or all of these works for personal or classroom use is granted without fee provided that the copies are not made or distributed for profit or commercial advantage AND that copies 1) bear this notice in full and 2) give the full citation on the first page. It is permissible to abstract these works so long as credit is given. To copy in all other cases or to republish or to post on a server or to redistribute to lists requires specific permission and payment of a fee. Contact Publisher@InformingScience.org to request redistribution permission. the exam or because they had reference notes readily available. Getting a good grade may be more important to them than to students who chose not to use notes. The better students may be more likely to prepare notes. 8) Results do not show why non-users of notes did not do as well. It could be because they feel notes will not help them or because they are less motivated. They may feel un- 
comfortable about referring to a "cheat sheet." They may feel better about having mastered the material than the note users, 9) The instructor may have been more proficient in teaching sections 2 and 4 in the evening after having rehearsed in day sections 1 and 3. (Please note, however, that section 5, a day class, showed the greatest improvement on the final.) 10) The outcome is based on three sections as the control group and could be an anomaly.

This article will be of most interest to faculty who teach information systems oriented courses but may be of interest to anyone who teaches or takes classes.

Keywords: IS Education, IT Education, CIS Education, Informatics Education, Exam Techniques

\section{Introduction}

Students often ask about the use of reference aids during exams in most disciplines. These aids are most commonly notes they have taken, textbooks, handouts, or perhaps access to information stored on computers and/or the Internet. Although the practice of using reference aids may be common, the only relevant research the author was able to locate was that of Wachsman. In the article, Should Cheat Sheets be Used as Study Aids in Economics Tests? Wachsman found that preparing and using a cheat sheet for Economics exams helped students improve test performance, but not enough to be statistically significant at the 5\% level (Wachsman, 2002). Other research of interest but not sufficiently related to this study to discuss are works by Barrier and Margavio in 1993, Campbell and Smith in 1997, and Whinston in 1994.

\section{Methodology}

After observing many course sections and students and after discussing the advantages and disadvantages of allowing use of reference notes, the author/professor formulated four hypotheses:

H0: Use of reference notes will significantly improve performance of a course section of students on an exam.

H1: Use of reference notes will not significantly improve performance of a course section of students on an exam.

H2: The choice to use reference notes will significantly improve performance of individual students on an exam.

H3: The choice to use reference notes not will significantly improve performance of individual students on an exam.

To test these hypotheses the professor proceeded to teach eight sections of the same course at the same university in the same way over a two-year period with the exception that Sections 1, 3, 4, 5 and 8 were allowed to use reference notes during the final exam whereas Sections 2, 6 and 7 were not.

\section{The Students}

Students were enrolled in eight sections of a junior level computer information systems (CIS) course within the business school at a mid-sized state university in the USA. The full professor who taught all sections holds a Ph.D. in business with an emphasis in information systems and also holds professional computer certifications.

The university has a policy of offering classes during the day and evening to accommodate students who work and have families. Sections 1, 5 and 6 met three times a week for 70 minutes per 
session during the day. Section 3, 7, and 8 met two times per week for 110 minutes per session in the afternoon. Sections 2 and 4 both met two times per week for 110 minutes in the evening.

All students in the eight sections had the same reading assignments, the same two exams and the same five sets of homework, comprised of using spreadsheet, database, internet, PowerPoint and diagramming software. Students were expected to participate in class and the majority did so by answering discussion questions at the back of chapters assigned in Introduction to Information Systems, 10th edition by James O'Brien (2001).

Students enrolled in the day sections $(1,3,5,6,7$, and 8$)$ were slightly younger than those in Sections 2 and 4 and tended to be full time students. Section 2 and 4 students mostly worked full time during the day and were enrolled in one or two evening classes.

More females than males were enrolled in all eight sections with the highest percentage of females being enrolled in the Section 8, an afternoon class. Section 5 students attended class most regularly $(83 \%)$ and Section 2 students attended class least often $(69 \%)$. Accurate roll records were not maintained for sections 7 and 8 , but the instructor believes the percentage of students attending was somewhere between sections 2 and 5. The demographic profile of students is summarized in Table 1.

\begin{tabular}{|c|c|c|c|c|c|c|c|c|}
\hline \multicolumn{9}{|c|}{ Table 1. Demographics } \\
\hline $\begin{array}{c}\text { DEMOGRAPHIC } \\
\text { ITEM }\end{array}$ & $\begin{array}{c}\text { SECTION } \\
1\end{array}$ & $\begin{array}{c}\text { SECTION } \\
2\end{array}$ & $\begin{array}{c}\text { SECTION } \\
3\end{array}$ & $\begin{array}{c}\text { SECTION } \\
4\end{array}$ & $\begin{array}{c}\text { SECTION } \\
5\end{array}$ & $\begin{array}{c}\text { SECTION } \\
6\end{array}$ & $\begin{array}{c}\text { SECTION } \\
7\end{array}$ & $\begin{array}{c}\text { SECTION } \\
8\end{array}$ \\
\hline $\begin{array}{l}\text { NO. OF STU- } \\
\text { DENTS TAKING } \\
\text { FINAL EXAM }\end{array}$ & 33 & 28 & 35 & 28 & 44 & 34 & 35 & 31 \\
\hline $\begin{array}{l}\text { TIME OF } \\
\text { MEETING }\end{array}$ & Day & Evening & Day & Evening & Day & Day & Day & Day \\
\hline $\begin{array}{l}\text { FREQUENCY } \\
\text { OF MEETINGS }\end{array}$ & $\begin{array}{l}3 \text { days per } \\
\text { week }\end{array}$ & $\begin{array}{l}2 \text { evenings } \\
\text { per week }\end{array}$ & $\begin{array}{l}2 \text { days per } \\
\text { week }\end{array}$ & $\begin{array}{l}2 \text { evenings } \\
\text { per week }\end{array}$ & $\begin{array}{l}3 \text { days per } \\
\text { week }\end{array}$ & $\begin{array}{l}3 \text { days per } \\
\text { week }\end{array}$ & $\begin{array}{l}2 \text { days per } \\
\text { week }\end{array}$ & $\begin{array}{l}2 \text { days per } \\
\text { week }\end{array}$ \\
\hline $\begin{array}{l}\text { STUDENT } \\
\text { MAJOR }\end{array}$ & $\begin{array}{l}\text { Business } \\
\text { Admini- } \\
\text { stration, } \\
\text { wide range } \\
\text { of options }\end{array}$ & $\begin{array}{l}\text { Business } \\
\text { Admini- } \\
\text { stration, } \\
\text { wide range } \\
\text { of options }\end{array}$ & $\begin{array}{l}\text { Business } \\
\text { Admini- } \\
\text { stration, } \\
\text { wide range } \\
\text { of options }\end{array}$ & $\begin{array}{l}\text { Business } \\
\text { Admini- } \\
\text { stration, } \\
\text { wide range } \\
\text { of options }\end{array}$ & $\begin{array}{l}\text { Business } \\
\text { Admini- } \\
\text { stration, } \\
\text { wide range } \\
\text { of options }\end{array}$ & $\begin{array}{l}\text { Business } \\
\text { Admini- } \\
\text { stration, } \\
\text { wide range } \\
\text { of options }\end{array}$ & $\begin{array}{l}\text { Business } \\
\text { Admini- } \\
\text { stration, } \\
\text { wide range } \\
\text { of options }\end{array}$ & $\begin{array}{l}\text { Business } \\
\text { Admini- } \\
\text { stration, } \\
\text { wide range } \\
\text { of options }\end{array}$ \\
\hline $\begin{array}{l}\text { PORTION OF } \\
\text { TIME WORK- } \\
\text { ING }\end{array}$ & $\begin{array}{l}\text { Most part } \\
\text { time }\end{array}$ & $\begin{array}{l}\text { Most full } \\
\text { time }\end{array}$ & $\begin{array}{l}\text { Most part } \\
\text { time }\end{array}$ & $\begin{array}{l}\text { Most full } \\
\text { time }\end{array}$ & $\begin{array}{l}\text { Most part } \\
\text { time }\end{array}$ & $\begin{array}{l}\text { Most part } \\
\text { time }\end{array}$ & $\begin{array}{l}\text { Most part } \\
\text { time }\end{array}$ & $\begin{array}{l}\text { Most part } \\
\text { time }\end{array}$ \\
\hline RELATIVE AGE & Younger & Older & Younger & Older & Younger & Younger & Younger & Younger \\
\hline $\begin{array}{l}\text { GENDER } \\
\text { DISTRIBUTION }\end{array}$ & $\begin{array}{l}68.8 \% \\
\text { female }\end{array}$ & $\begin{array}{l}62.1 \% \\
\text { female }\end{array}$ & $\begin{array}{l}55.6 \% \\
\text { female }\end{array}$ & $\begin{array}{l}71.4 \% \\
\text { female }\end{array}$ & $\begin{array}{l}56.8 \% \\
\text { female } \\
\end{array}$ & $\begin{array}{l}61.8 \% \\
\text { female } \\
\end{array}$ & $\begin{array}{l}72.3 \% \\
\text { female }\end{array}$ & $\begin{array}{l}74.2 \% \\
\text { female } \\
\end{array}$ \\
\hline $\begin{array}{l}\text { ATTENDANCE: } \\
\text { portion of class } \\
\text { meetings attended }\end{array}$ & $74.4 \%$ & $69.3 \%$ & $77.7 \%$ & $75.0 \%$ & $83 \%$ & $76.6 \%$ & N/A & N/A \\
\hline
\end{tabular}

\section{The Exams}

All students took the same midterm and final exam. Both exams comprised 80 questions. All questions were multiple choice and had four items to choose from. Questions were based on a combination of lecture and reading assignments. The instructor made sure the material tested was covered in lectures and could be found in reading assignments as well. Students had at least 100 minutes to complete the final exam. Students using notes took about 12 minutes longer on average than students not using notes. Exams were machine scored. The final exam focused on material covered since the midterm, and a sample of questions on the final exam is shown in Table 2.

No section was allowed the use of notes during the midterm. For the final exam, the instructor flipped a coin to select which sections would be allowed to use notes. Five of the eight sections were allowed use of one page ( $81 / 2$ by 11 inches) of handwritten notes for the final exam. Sections 2, 6 and 7 were not allowed to use any notes. Thus, the three main groups of students are 1) those 
choosing to use notes, 2) those choosing not to use notes and 3) those not allowed to use notes. The sections not allowed to use notes were unaware that other sections were allowed the use of notes. To ensure fairness, course grades were decided by individual section; that is, sections allowed to use notes were not combined with sections not allowed to use notes when making grade decisions.

\begin{tabular}{|l|}
\hline \multicolumn{1}{|c|}{ Table 2. Sample of Questions on Final Exam } \\
\hline \multicolumn{1}{|c|}{ *denotes correct choice } \\
\hline 1. Internet-using companies list which of the following as the top business value derived from \\
business applications on the Internet and Internet-based technologies? \\
A) Substantial cost savings because applications using the Internet are typically less ex- \\
pensive to develop, operate, and maintain than traditional systems. \\
B) Ease of development and maintenance for corporate intranet applications than tradi- \\
tional mainframe or client/server systems. \\
C) Support via the Internet and the Web for interactive marketing and customer service \\
and other electronic commerce applications. \\
D) All the above. * \\
\hline 2. If a company uses the Internet to enable its members at different organizations and people at \\
different locations to work together as a virtual team, they would be using the Internet to support: \\
A) Enterprise communications and collaboration. * \\
B) Human resource management. \\
D) Electronic commerce.
\end{tabular}

3. The steps in the systems development life cycle (SDLC) are:

A) Investigation, analysis, testing, design, and maintenance.

B) Analysis, testing, investigation, implementation, and maintenance.

C) Investigation, analysis, design, implementation, and maintenance. *

D) Analysis, testing, design, implementation, and maintenance.

4. Which one of the following would NOT be considered as a way that a computer virus can enter a computer system?
A) E-mail and file attachments.
B) Borrowed copies of software.
C) Downloaded copies of shareware.
D) Running antivirus programs. *

5. A chief information officer:

A) Does not have responsibility for a firm's office information systems.

B) Has major responsibility for long-term planning and strategy. *

C) Is expected to closely supervise the internal operations of the information services department, but has limited responsibility for interfacing with other departments.

D) Develops and administers training programs for information services personnel and computer users. 


\section{Quality of the Notes}

Students put their names on their one page of notes and submitted these with the final exam. This enabled the instructor to link use of notes with the test scores of specific individuals. One page of hand-written notes on $81 / 2 \times 11$ inch paper may not sound like much. Yet some students wrote so small that the instructor needed a powerful magnifying glass to decipher the notes. Other students filled less than one quarter of a page with average size handwriting. Indeed, the quality of notes prepared and the number of words varied considerably.

\section{Analysis and Findings}

\section{How Do the Course Sections of Students Using Notes Compare to Those Not Using Notes?}

Table 3 and Figure 1 summarize by section the averages of scores on exams and the number of students taking the exams. Interestingly, seven of the eight sections had higher average scores on the final exam than on the midterm. Section $7 \mathrm{did}$ not use notes but was extremely consistent to achieve the same average score for both the midterm and final exams. Although sections 2 and 6 did not use notes, they showed substantial improvement. Sections 1 and 3 showed the least amount of improvement even though they were both allowed to use notes. Thus, the results provide mild support for hypothesis 1 , the null hypothesis.

\begin{tabular}{|c|c|c|c|c|c|}
\hline & MIDTERM & MIDTERM & FINAL EXAM & FINAL EXAM & CHANGE \\
\hline & \# STUDENTS & $\begin{array}{l}\text { AVERAGE SCORE } \\
\text { OF } 80 \text { QUESTIONS }\end{array}$ & \# STUDENTS & $\begin{array}{l}\text { AVERAGE SCORE } \\
\text { OF } 80 \text { QUESTIONS* }\end{array}$ & IN SCORE \\
\hline SECTION 1 & 33 & 50.00 & 33 & 52.27 & +2.27 \\
\hline SECTION 2 & 32 & 55.00 & 28 & 60.25 & +5.25 \\
\hline SECTION 3 & 35 & 58.43 & 35 & 61.37 & +2.94 \\
\hline SECTION 4 & 29 & 57.62 & 29 & 61.18 & +3.56 \\
\hline SECTION 5 & 43 & 53.60 & 44 & 59.20 & +5.60 \\
\hline SECTION 6 & 36 & 50.90 & 34 & 55.70 & +4.80 \\
\hline SECTION 7 & 35 & 53.69 & 35 & 53.69 & 0.00 \\
\hline SECTION 8 & 33 & 51.94 & 31 & 56.13 & +4.19 \\
\hline AVG ALL SEC. & 34.50 & 53.90 & 33.63 & 57.47 & +3.58 \\
\hline
\end{tabular}




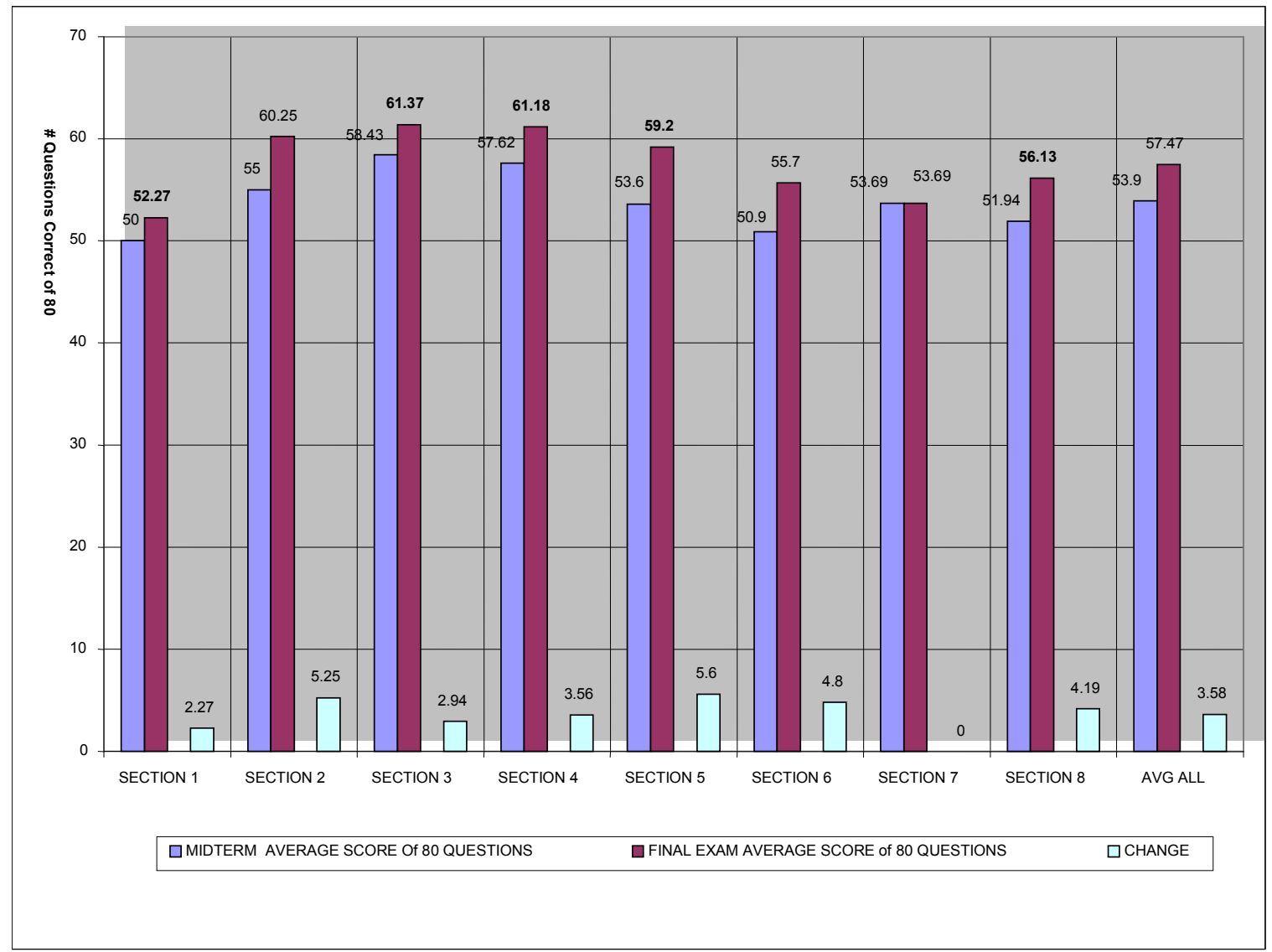

Figure 1: Visual summary or exam results for student having choice of whether or not to use notes in 3 sections of CIS 3060 CIS in Management

\section{How Do Individual Students Choosing NOT to Use Notes Compare to Those Who Do?}

For three of the five sections allowed to use notes, the author tracked performance of how the students choosing not to use notes performed. Table 4 highlights and summarizes for these three sections $(1,5$ and 8$)$ the averages of scores on exams and Figure 2 portrays a visual summary of the exam results. Interestingly, all three sections had higher average scores on the final exam than on the midterm. Section 5 shows the most improvement. It also has the highest portion of students choosing to use notes.

Table 4. Summary of Exam Results for Students Having the Choice of Whether or Not to Use Notes in 3 Sections of CIS 3060 (CIS in Management)

\begin{tabular}{|c|c|c|c|c|c|c|c|}
\hline & $\begin{array}{c}\text { TOTAL NO. } \\
\text { OF STU- } \\
\text { DENTS } \\
\text { ENROLLED }\end{array}$ & MIDTERM & MIDTERM & FINAL EXAM & $\begin{array}{c}\text { FINAL } \\
\text { EXAM }\end{array}$ & CHANGE & \%CHANGE \\
\cline { 3 - 8 } & $\begin{array}{c}\text { SCORE OF } \\
80 \text { QUES- } \\
\text { TIONS }\end{array}$ & $\begin{array}{c}\text { PERCENT } \\
\text { SCORE }\end{array}$ & $\begin{array}{c}\text { AVERAGE } \\
\text { SCORE OF } \\
80 \text { QUES- } \\
\text { TIONS }\end{array}$ & $\begin{array}{c}\text { PERCENT } \\
\text { SCORE }\end{array}$ & IN SCORE & IN SCORE \\
\hline SECTION 1 & 33 & 50.00 & 62.5 & 52.27 & 65.3 & 2.27 & 4.5 \\
\hline SECTION 5 & 44 & 53.60 & 67.0 & 59.20 & 74.0 & 5.60 & 10.4 \\
\hline SECTION 8 & 31 & 51.94 & 64.9 & 56.13 & 70.2 & 4.19 & 8.1 \\
\hline AVERAGE & 36 & 51.85 & 64.8 & 55.87 & 69.8 & 4.02 & 7.8 \\
\hline
\end{tabular}




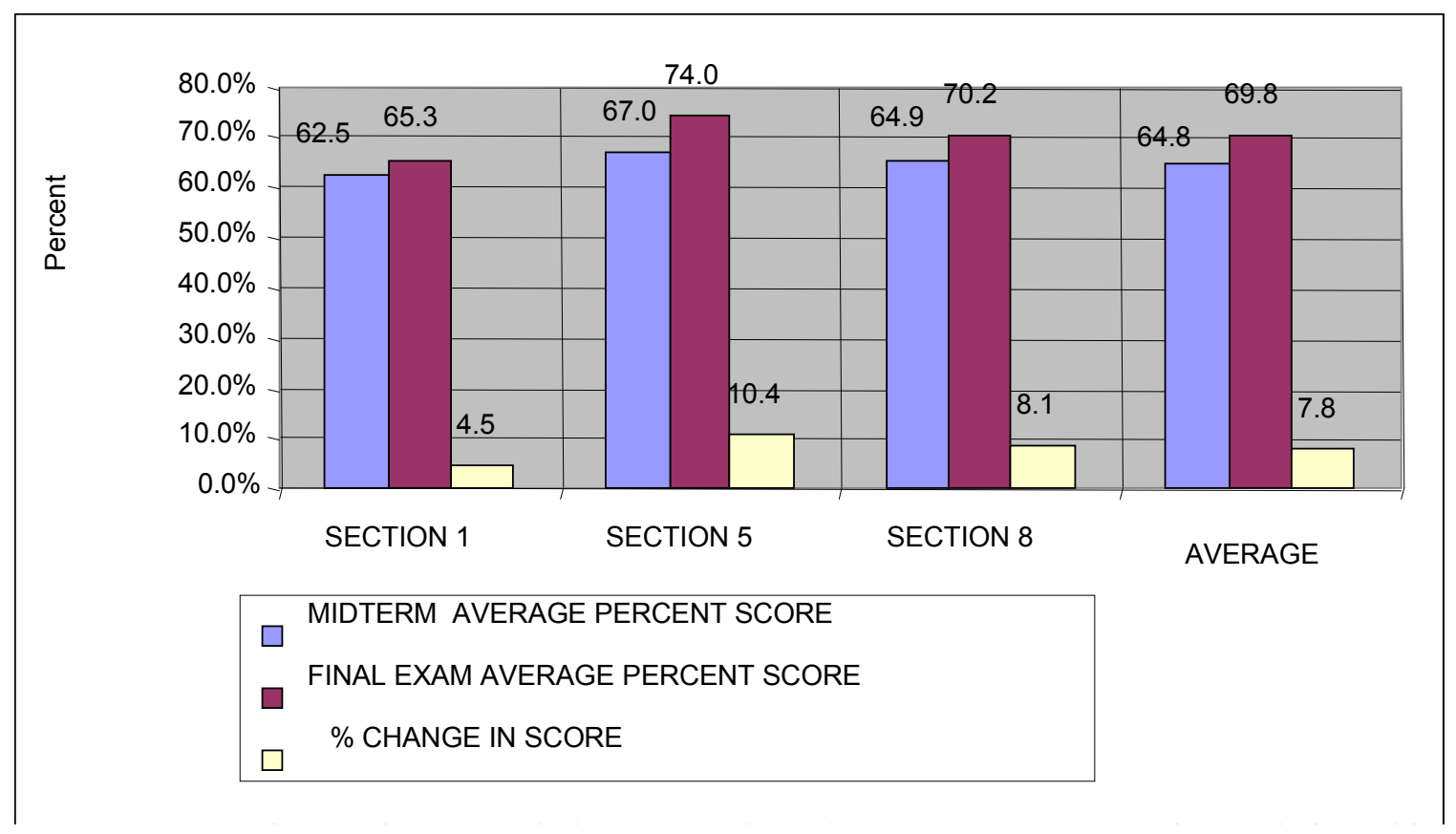

Figure 2: Summary of Exam Results for Students Having Choice of Whether or Not to Use Notes in 3 Sections of CIS 3060 (CIS in Management)

Next, the author combined data for all three sections who were allowed to use notes and compared results of those individual students who chose to use notes on the final exam with those who did not. As shown in Table 5, of the 108 students observed, 83 of them (76.85\%) chose to use notes and 25 students $(23.15 \%)$ chose not to. Table 6 shows average scores on the final exam by section and the overall average. Figure 3 provides a visual comparison of the averages. Ideally, all students in these three sections would have chosen to use notes, but since they did not it is possible results may be skewed.

\begin{tabular}{|c|c|c|c|c|c|c|}
\hline SECTION & $\begin{array}{c}\text { NO. OF } \\
\text { STUDENTS } \\
\text { USING NOTES }\end{array}$ & $\begin{array}{l}\text { PERCENT OF } \\
\text { STUDENTS } \\
\text { USING NOTES }\end{array}$ & $\begin{array}{c}\text { NO. OF } \\
\text { STUDENTS } \\
\text { NOT USING } \\
\text { NOTES }\end{array}$ & $\begin{array}{l}\text { PERCENT OF } \\
\text { STUDENTS } \\
\text { NOT USING } \\
\text { NOTES }\end{array}$ & $\begin{array}{c}\text { TOTAL } \\
\text { ENROLLED }\end{array}$ & $\begin{array}{c}\text { PERCENT } \\
\text { OF TOTAL } \\
\text { ENROLL- } \\
\text { MENT }\end{array}$ \\
\hline SECTION 1 & 23 & 69.70 & 10 & 30.30 & 33 & 100 \\
\hline SECTION 5 & 38 & 86.36 & 6 & 13.64 & 44 & 100 \\
\hline SECTION 8 & 22 & 70.97 & 9 & 29.03 & 31 & 100 \\
\hline TOTAL & 83 & 76.85 & 25 & 23.15 & 108 & 100 \\
\hline
\end{tabular}

\begin{tabular}{|c|c|c|c|c|c|c|}
\hline \multicolumn{7}{|c|}{$\begin{array}{c}\text { Table 6. Summary of Final Exam Scores by Section and Overall for Students Choosing to Use Notes Compared to } \\
\text { Those Who Did Not in CIS } 3060\end{array}$} \\
\hline \multirow[t]{2}{*}{ SECTION } & \multicolumn{3}{|c|}{ STUDENTS USING NOTES } & \multicolumn{3}{|c|}{ STUDENTS NOT USING NOTES } \\
\hline & $\begin{array}{l}\text { NO. OF STU- } \\
\text { DENTS }\end{array}$ & $\begin{array}{l}\text { AVERAGE } \\
\text { SCORE }\end{array}$ & PERCENT & $\begin{array}{l}\text { NO. OF STU- } \\
\text { DENTS }\end{array}$ & $\begin{array}{l}\text { AVERAGE } \\
\text { SCORE }\end{array}$ & PERCENT \\
\hline SECTION 1 & 23 & 53.87 & $67.34 \%$ & 10 & 48.60 & $60.75 \%$ \\
\hline SECTION 5 & 38 & 59.50 & $74.38 \%$ & 6 & 57.00 & $71.25 \%$ \\
\hline SECTION 8 & 22 & 56.77 & $70.96 \%$ & 9 & 54.56 & $68.20 \%$ \\
\hline AVG 3 SECTIONS & 27.67 & 57.22 & $71.53 \%$ & 8.33 & 52.76 & $65.95 \%$ \\
\hline
\end{tabular}




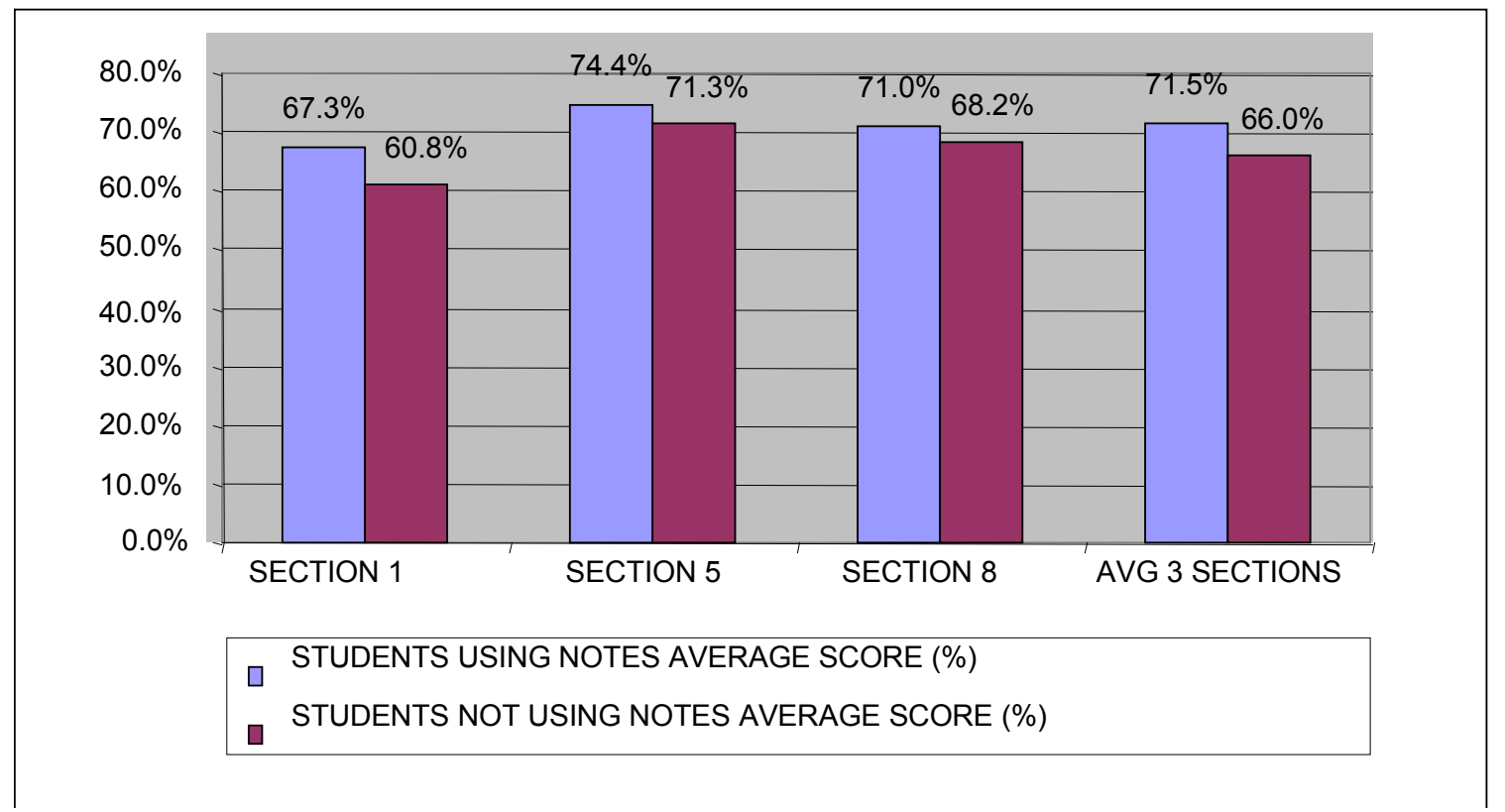

Figure 3: Visual summary of final exam scores by section and overall for students choosing to use notes compared to those who did not in CIS 3060

Using SAS software, t-tests were conducted to determine whether performance on exams by individual students using notes is statistically significant at the $95 \%$ confidence level. As shown in Table 7, by assuming variances will be equal, the t-score is 2.56 , compared to 2.28 when unequal variances are assumed. In either case, these results show that individual students in sections 1,5 , and 8 who chose to use notes achieved significantly higher exam scores compared to students who chose not to use notes. Thus, these results support hypothesis 2 , which states the choice to use reference notes, will significantly improve performance of individual students on an exam.

\begin{tabular}{|l|l|l|l|l|}
\hline \multicolumn{5}{|c|}{ Table 7a. T-Test Results Comparing Students Who Chose to Use Notes With Those } \\
Who Chose Not to Use Notes \\
\hline & $\begin{array}{c}\text { No. of } \\
\text { Students }\end{array}$ & $\begin{array}{c}\text { Mean Score } \\
\text { on Exam }\end{array}$ & $\begin{array}{c}\text { Standard } \\
\text { Deviation }\end{array}$ & $\begin{array}{c}\text { Standard } \\
\text { Error of the } \\
\text { Mean }\end{array}$ \\
\hline $\begin{array}{l}\text { Students using } \\
\text { notes }\end{array}$ & 83 & 57.22 & 7.2 & 0.8 \\
\hline $\begin{array}{l}\text { Students using } \\
\text { NO Notes }\end{array}$ & 25 & 52.76 & 8.9 & 1.8 \\
\hline
\end{tabular}




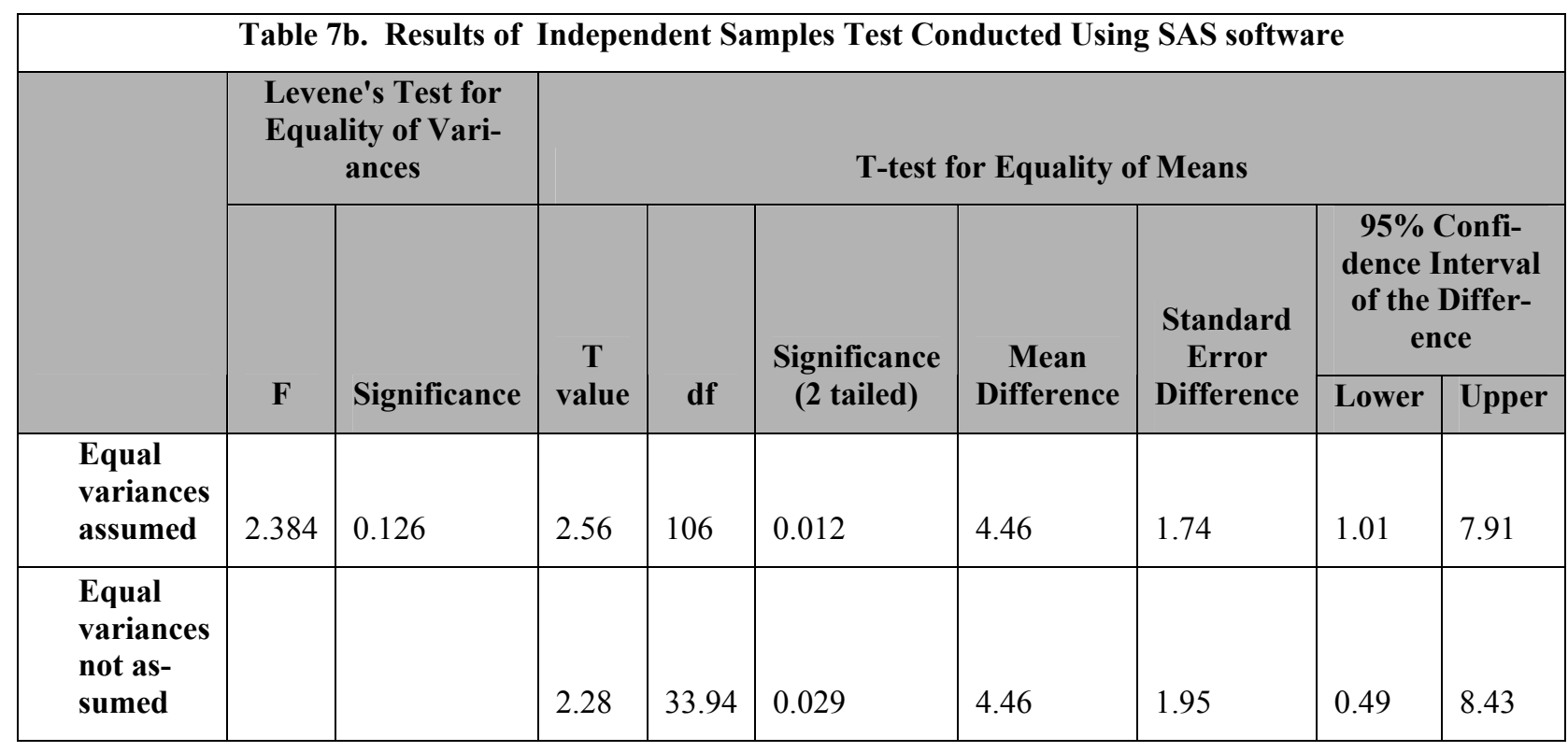

\section{Explanations}

One or many of the following 10 factors may have influenced the students and the results: 1) Since use of notes is optional, many students may choose not to use them and thus negate the potential impact on a course section, 2) Allowing notes may instill a false sense of confidence such that students may procrastinate and not prepare thoroughly for the exam, 3) Limiting reference notes to one page may be too similar to allowing no reference notes, 4) The opportunity to use notes may provide an incentive for some students to prepare thoroughly for the exam, 5) The quality of student-prepared notes can vary considerably. 6) The final exam, although difficult, may be inherently easier than the midterm, 7) Results do not show why students who prepared notes did slightly better. It could be because they spend more time and mental synthesis in preparation for the exam or because they had reference notes readily available. Getting a good grade may be more important to them than to students who chose not to use notes. The better students may be more likely to prepare notes. 8) Results do not show why non-users of notes did not do as well. It could be because they feel notes will not help them or because they are less motivated. They may feel uncomfortable about referring to a "cheat sheet." They may feel better about having mastered the material than the note users, 9) The instructor may have been more proficient in teaching sections 2 and 4 in the evening after having rehearsed in day sections 1 and 3. (Please note, however, that section 5, a day class, showed the greatest improvement on the final.) 10) The outcome is based on three sections as the control group and could be an anomaly.

\section{Conclusion}

Although the sections of the course where students used notes did slightly better, overall, there is insufficient evidence to support hypothesis 0 , the primary hypothesis, that use of notes on CIS exams enhances student performance. Among the subset of students who had the choice of whether or not to use notes, exam scores for those who chose to use notes were significantly higher than the scores of students who chose not to use notes, thus supporting hypothesis 2 . This study suggests that individual students will perform slightly better on exams if they prepare reference notes to use. Both faculty and students who want to see good test results have reason to promote the use of reference notes during exams. 
Since past research in this area is limited, it is ripe for additional exploration. A comparison of individual student performance on the final exam could be compared to the midterm as a way of measuring whether or not test scores of students who choose to use notes improves significantly. The quality of notes prepared could be compared to how relatively well students perform. A student survey or interviews could be conducted to explore reasons why students chose to use notes or not. Still other variables worthy of study include student demographics (portion male/female, etc.), attendance, time of day the class meets, exam style (multiple choice vs. true false vs. essay) and internet-based vs. face-to-face sections.

In the virtual classroom of the future, exploratory research such as this will be more challenging to conduct because of the difficulty in controlling reference materials available to students during exams. Exams as we know them today may become extinct!

\section{References}

Barrier, T. B., \& Margavio, T. M. (1993). Pretest-posttest measure of introductory computer students' attitudes toward computers. Journal of Information Systems Education, 5(2), 53-58.

Campbell, W.E., \& Smith, K. A. (1997). New paradigms for college teaching. Interaction Book Company.

O’Brien, J. (2001). Introduction to information systems (10 $0^{\text {th }}$ edition). Boston: Irwin-McGraw Hill.

Wachsman, Y. (2002). Should cheat sheets be used as study aids in economics tests? Economics Bulletin, $1(1), 1-10$.

Whinston, A. B. (1994). Reengineering education. Journal of Information Systems Education, 6(3), 126133.

\section{Biography}

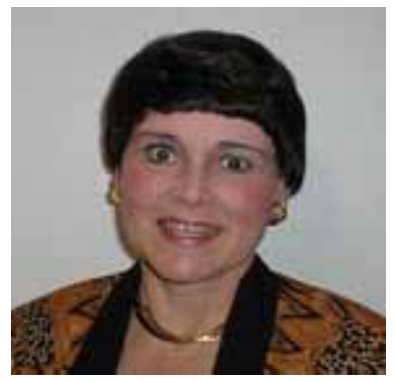

Dr. Doris Duncan, CCP, CSP, CDP, CDE, is the Director of MBA Programs and Professor of Computer Information Systems at California State University, East Bay (formerly Hayward), USA. Extensive service to CSUEB includes serving as the CIS area coordinator and graduate advisor for CIS and e-business programs. Duncan was a Visiting Professor of Information Systems at the University of Washington, Seattle, 1997-98 and the Program Director of Information Systems at Golden Gate University, San Francisco, 1982-83. Her thirty plus years of experience in information technology include communications consultant and marketing manager for AT\&T, program director for Input, Inc., and member of senior management consulting staff at Quantum Science Corporation. She has had consulting engagements with several businesses, including Dialog Information Services, Pacific Bell Telephone Co., Valicert, Golden Gate University, Prentice Hall, McGraw-Hill Book Co. Dr. Duncan authored a book, Computers and Remote Computing Services, and has published over 60 refereed journal articles and conference presentations. She is also a frequent speaker before professional groups. Duncan is past president of the Data Processing Management Association, San Francisco Chapter, and has served on the Board of Directors of several professional societies, including DPMA, the DPMA Special Interest Group in Education, and the Institute for Certification of Computer Professionals Education Foundation. Duncan has served on the editorial review board for the Journal of Information Systems Education, the Journal of Informatics Education and Research and as a reviewer for many textbooks and conference proceedings. Duncan was selected "Computer Educator of the Year" in 1997 by the International Association of Computer Information Systems. 